\title{
Physico-Chemical and Microbial Quality of Greywater from Various Households in Homa Bay Town
}

\author{
Kiplagat Kotut*, Victor G. Nganga and Francis W. Kariuki
}

Plant and Microbial Sciences Department of Kenyatta University, P.O. Box 43844 GPO 00100 Nairobi, Kenya

\begin{abstract}
In recent years concerns over dwindling reserves of ground water and overloaded or costly sewage treatment plants has generated much interest in the reuse or recycling of greywater. Re-use of greywater offers several advantages including a reduction in the demand on potable water supplies. Despite the prevalent direct reuse of greywater, especially in water scarce areas, its quality is not well documented. This study determined the physico-chemical and microbial quality of greywater produced by households in Homa Bay town. Most of greywater generated had a higher electrical conductivity and salinity and lower concentration of dissolved oxygen. Greywater $\mathrm{pH}$ values varied widely but were mostly higher than that of clean water. Biological oxygen demand varied widely (410-6250 mg L $\mathrm{L}^{-1}$ ). Total coliform (TC) counts in greywater samples ranged from 1.3 to 7.6 colony forming units (CFU)/ $100 \mathrm{~mL}$ while fecal coliform (FC) counts varied between 3000 and 7.4 million CFU/ $100 \mathrm{~mL}$. Field observations showed that the variation in TC and FC counts resulted from differences in the level of households' personal hygiene, difference in the intensity of greywater reuse and duration of storage. Among the potentially pathogenic bacteria investigated, Salmonella was the most frequent, occurring in $31 \%$ of all the greywater samples collected. Vibrio occurred in the least number of samples (9\%). The study concludes that greywater produced is most likely to be contaminated by pathogenic bacteria and should therefore be disinfected prior to reuse.
\end{abstract}

Keywords: Greywater, Homa Bay, coliforms, Salmonella, Shigella, Vibrio.

\section{INTRODUCTION}

The lakeshore population of the Lake Victoria Basin is fast growing with one of the highest population growth rates in the world [1]. A general feature of urban settlements in the Lake Basin is water scarcity and poor wastewater disposal systems. Domestic wastewater comprises blackwater (from toilets) and greywater (from bathroom, laundry and kitchen) [2]. The environmental effects of the two wastewater types are not usually the same. For example, they differ in the rate of decay of the pollutants contained. Blackwater consists largely of organic compounds that decompose slowly when placed in water while the decay of greywater is faster owing to the presence of organics which are, relative to the organics in blackwater, more readily available to micro-organisms. Because of its rapid decomposition rate, greywater discharged into a stream or a lake will have a more immediate impact on the recipient body of water at the point of discharge than combined wastewater. Other differences include a comparatively low pathogen load and a $90 \%$ less nitrogen in greywater as compared to blackwater [3]. Many studies focusing on problems associated with blackwater have been carried out $[2,4]$. However, limited attention has been given to greywater, which constitutes about 50 to $80 \%$ of the

\footnotetext{
*Address correspondence to this author at the Plant and Microbial Sciences Department of Kenyatta University, P.O. Box 43844 GPO 00100 Nairobi, Kenya; Tel: +254-20-788250; Fax: +254-20-811575;

E-mail: kkotut63@yahoo.com
}

wastewater generated by households $[5,6]$. In areas of low income and water scarcity, greywater reuse for irrigated agriculture is a common practice. Greywater is rich in total nitrogen ( 5 to $22 \mathrm{mg} \mathrm{L}^{-1}$ ) and total phosphorus $(0.2$ to $3.9 \mathrm{mg}$ $\left.\mathrm{L}^{-1}\right)$, has easily biodegradable organic content and relatively low pathogen content [3]. However, its safety is not guaranteed, particularly as relates to the potential for transmission of diseases as it is usually contaminated with faecal coliforms and chemical pollutants from bathing and laundry. Worldwide, a progressive decrease in the supply of potable water combined with an increase in the cost of water supply has in the recent past generated much interest in the reuse of the various types of wastewater. Many reports on the reuse potential of wastewater in cities of developing countries are available [7]. Similarly, treated wastewater reuse for irrigation, landscape and surface or groundwater replenishment purposes is being widely implemented globally [7, 8]. This practice serves as an efficient and valuable way to cope with the scarcity of water resources and severity of water pollution [9]. Although the reuse practice is accompanied by a number of benefits, which include the enhancement of water balances and soil nutrition by the nutrients existing in the treated effluents, there are still a number of unanswered questions related to this practice. It is perhaps due to the perception that it is the cleaner of the wastewaters that greywater has received the most attention $[10,11]$ and is considered to be the potential solution for the provision of non-potable water to water deprived regions worldwide [12]. Experiences from many parts of the world indicate that greywater can be 


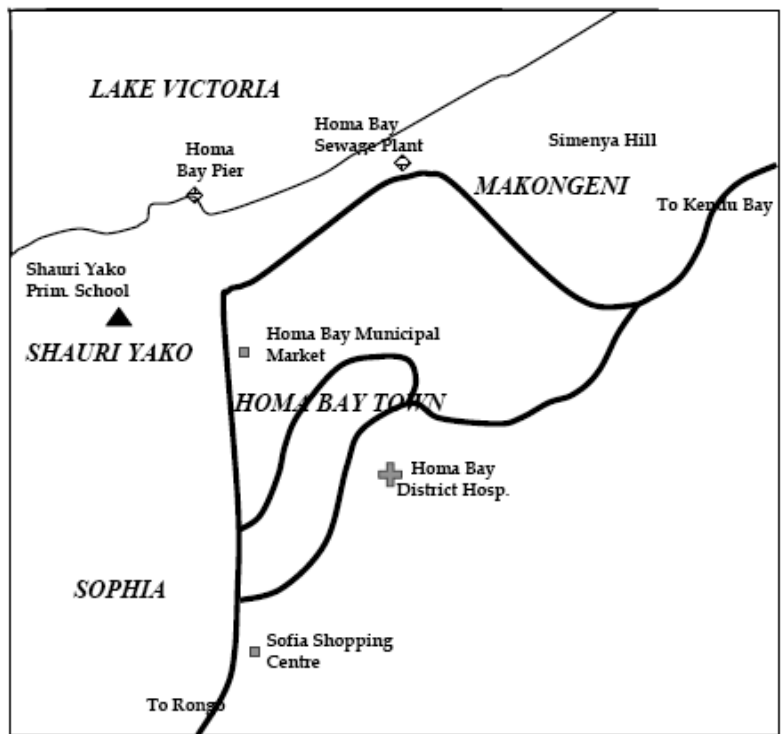

Fig. (1). Map of Homa Bay Town showing the sampling sites.

an effective alternative source of water [13]. In recent years, a number of greywater treatment technologies have been tested in different countries of the West $[14,15]$ where there is a better understanding of the quality greywater produced. However, in developing countries, the main barrier to the wider and faster dissemination of suitable greywater systems is the lack of knowledge and experience [16]. Scientific information on greywater characteristics is scarce as most of the available data on wastewater is based on combined wastewater.

A general feature of urban settlements in the drier areas of the Lake Victoria Basin is water scarcity and poor wastewater disposal systems. Greywater is commonly disposed untreated onto the ground and into open storm drains where they may form open pools of smelly waters that are ideal breeding grounds for mosquitoes etc. In such areas, an opportunity to reuse wastewater can alleviate the water scarcity challenges as well as the health hazards associated with its unsanitary disposal. In sections of the basin, where water supply is infrequent or insufficient, some limited reuse of greywater is practiced. However, very little, if any, information is available on the physico-chemical and bacteriological quality of the greywater produced. Hence the potential risk to human health arising from the reuse of this water is unknown.

The aim of this study was to determine the physicochemical and bacteriological quality of greywater produced by households in Homa Bay town. The results provide a better insight into the challenges associated with direct reuse of the greywater. The physico-chemical and microbiological data collected presents the residents of the region with empirical data on the implication of direct reuse of greywater. The data can also assist policy makers in formulating guidelines on reuse of greywater and form a useful baseline for the design and development of greywater treatment technologies.

The general objective of the present study was to determine the physico-chemical and bacterial properties of grey- water from various residential areas of of Homa Bay town. The specific objectives of the study were to determine:

- The levels of selected physico-chemical properties of greywater from households in different residential areas of the Homa Bay town.

- The bacterial load and quality of greywater from households in different residential areas of Homa Bay town.

\section{MATERIALS AND METHODS}

\section{Study Site}

Homa Bay Town (Fig. 1) is located along the North Eastern part of Lake Victoria, 105 kilometers South of Kisumu City and 405 kilometers southwest of Nairobi. The total area of the municipality is about $197 \mathrm{~km}^{2}$, of which Lake Victoria covers about $97 \mathrm{~km}^{2}$. The town has several residential estates, the most populous being Sophia, Shauri Yako and Makongeni. Homa Bay is semi-arid with an average annual rainfall of between $250 \mathrm{~mm}$ and $700 \mathrm{~mm}$ and generally high temperatures during most of the year. The town has an estimated population of about 90,000 with an average growth rate of 2.5 per cent per annum. The main source of water for Homa Bay town is Lake Victoria. However, even with the lake nearby, the town suffers from frequent shortages of clean piped water. The total water supply is designed to deliver about $3,500 \mathrm{~m}^{-3} \mathrm{~d}^{-1}$ against a total water demand of $5,100 \mathrm{~m}^{-3} \mathrm{~d}^{-1}$ and $3,100 \mathrm{~m}^{-3} \mathrm{~d}^{-1}$ for the larger municipality and the main town respectively [17]. However, the system is currently producing only about $2,000 \mathrm{~m}^{-3} \mathrm{~d}^{-1}$ leaving a shortfall of $1,000 \mathrm{~m}^{-3} \mathrm{~d}^{-1}$ while the other $100 \mathrm{~m}^{-3} \mathrm{~d}^{-1}$ is obtained from other sources including shallow wells, springs, boreholes, and directly from the lake.

\section{Study Methodology}

\section{Sample Collection}

Greywater samples were collected early in the morning when cleaning in most households was at its peak. Households were chosen randomly (the choice of household to sample was based on the results of a random walk across the main street of residential areas chosen). After walking a distance of approximately $50 \mathrm{~m}$ from the last household sampled, the next household found washing was sampled. At least fifteen households were sampled in each visit. Five households provided samples from bathrooms, five from kitchens and five from laundry activities. The Estates targeted in each visit were Sophia, Shauri Yako and Makongeni (Fig. 1). Additionally, greywater samples were also collected from the main town along the section located between Shauri Yako to Makongeni Estates. The samples collected were appropriately fixed in the field and transported on ice to the laboratory, where analysis commenced upon arrival. Where immediate analysis was not possible, the samples were held at $4{ }^{\circ} \mathrm{C}$ until the time of analysis [18].

\section{Physico-Chemical Properties}

Water temperature, conductivity, $\mathrm{pH}$ and salinity were measured directly in the field using a WTW Multiline P4 meter (Weilheim, Germany). Biological oxgen demand $\left(\mathrm{BOD}_{5}\right)$ was established through the titrimetric determination 

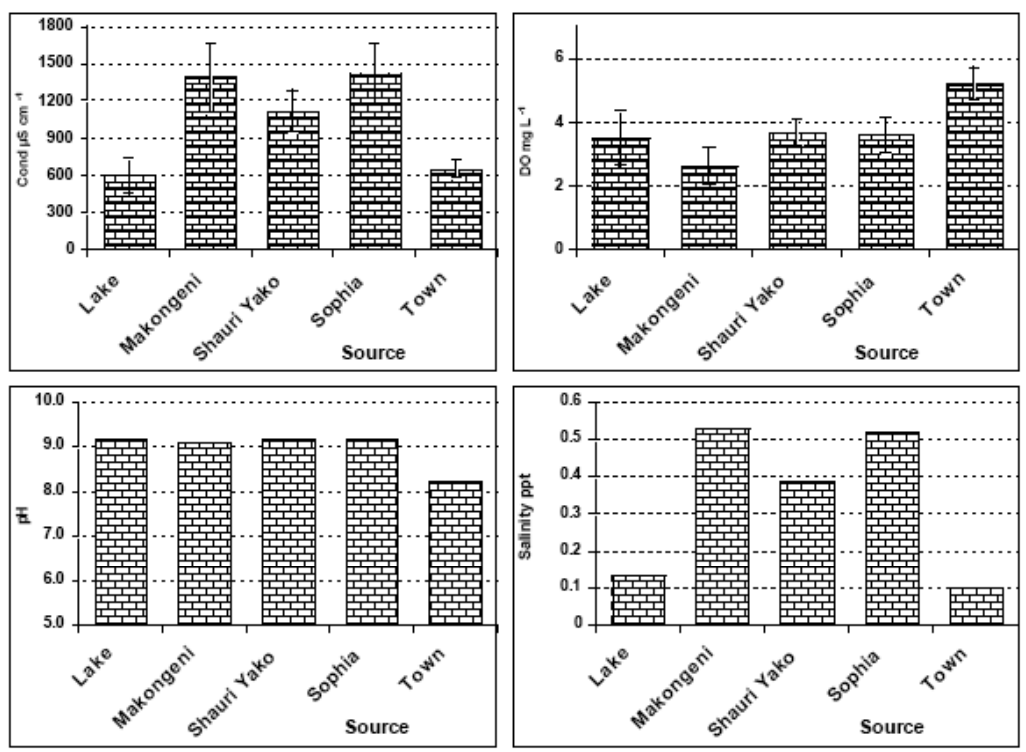

Fig. (2). Mean levels of electrical conductivity, dissolved oxygen, salinity and median $\mathrm{pH}$ of greywater samples obtained from different sources in Homa Bay. Vertical bars represent \pm SE.

of dissolved oxygen before and after incubation of appropriately diluted samples for five days [18].

\section{Bacterial Load}

Total coliforms were determined in duplicate using the membrane filtration technique. An amount of $100 \mathrm{ml}$ of an appropriately diluted sample of greywater from each source was filtered through $0.45 \mu \mathrm{m}$ pore size sterilized membrane filter pad and the filter placed face up on the petri plate containing endo agar and incubated at $37{ }^{\circ} \mathrm{C}$ for 24 hours. The colonies formed were counted using a colony counter to obtain total bacteria per $100 \mathrm{ml}$ of each water sample. Selected colonies from endo agar plates were next subcultured in duplicate brilliant green lactose bile fermentation broth tubes with a Durham tube inserted and incubated at $37{ }^{\circ} \mathrm{C}$ for 24 hours and checked for gas formation. A drop of culture from the positive lactose broth culture was streaked onto a nutrient agar slant and incubated at $37{ }^{\circ} \mathrm{C}$ for 24 hours. The colonies formed were gram stained to check for the characteristic gram negative and non-spore forming bacilli [18]. For the determination of fecal coliforms (thermotolerant coliforms), a known volume of an appropriately diluted water sample was passed through a sterile membrane filter pad. The membrane filter was next placed in a Petri-plate containing mEndo agar and incubated at $44.5^{\circ} \mathrm{C}$. A color change from red to yellow in the culture medium was indicative of the presence of thermotolerant coliforms. The colonies formed were counted using colony counter the results expressed as colony forming units per $100 \mathrm{~mL}$ (CFU per $100 \mathrm{~mL}$ ) [18].

\section{Pathogenic Bacteria}

The presence of three pathogenic bacteria, Salmonella, Shigella and Vibrio cholerae were tested in the greywater samples collected. To test for the presence of Salmonella and Shigella, a one-mililitre water sample was enriched with selenite $\mathrm{F}$ broth followed by careful streaking on salmonellashigella agar. Presence of Salmonella and Shigella spp were confirmed by transferring the suspect colonies onto Triple
Sugar Iron (TSI) agar [19]. Further confirmation was also conducted by inoculating the colonies onto motility indole urease agar, which differentiates between motile Salmonella and non-motile Shigella. Presence of Vibrio cholerae was determined in three successive stages. First, the sample was enriched in sterile alkaline peptone water dispensed in $10 \mathrm{ml}$ tubes and incubated for 18 hours at $35{ }^{\circ} \mathrm{C}([18])$. Secondly, a loopful of the broth was then carefully streaked on Petriplate containing Thiosulfate Citrate Bile Salts Sucrose (TCBS) agar and incubated at $35{ }^{\circ} \mathrm{C}$ for 24 hours. Thirdly, serological tests were carried out on suspect colonies to confirm the presence of Vibrio cholerae.

\section{RESULTS}

\section{Physico-Chemical Conditions}

The physico-chemical properties of greywater samples collected from various estates (Shauri Yako, Sofia, Makongeni, Lake Victoria, Town centre) varied widely. Electrical conductivity (EC) ranged from 60 to $4470 \mu \mathrm{S} \mathrm{cm} \mathrm{c}^{-2}$ while values in clean water varied between 143 and $187 \mu \mathrm{S} \mathrm{cm}^{-2}$. Among the different residential areas, mean EC ranged from 599.7 (Lake) to 1420.6 (Sofia) (Fig. 2, Table 1). However, based on a one way ANOVA test the difference in EC among the greywater sources was not significant $(\mathrm{F}=0.73, \mathrm{P}$ $=0.6$ ). Mean $\mathrm{EC}$ for the different types of greywater (from different cleaning operations) varied between 437.0 (bath) and $1526.7 \mu \mathrm{S} \mathrm{cm}^{-2}$ (laundry) (Fig. 3, Table 2). A one way ANOVA test revealed that the difference in mean EC of the different greywater sources was significant $(\mathrm{F}=3.99, \mathrm{P}=$ $0.02)$ with bath water having the lowest mean EC $(437.0 \mu \mathrm{S}$ $\left.\mathrm{cm}^{-2}\right)$ while laundry water had the highest $\left.(1526.7 \mu \mathrm{S} \mathrm{cm})^{-2}\right)$. Dissolved oxygen (DO) concentration of greywater ranged from below the limit of detection (0.0) to $8.0 \mathrm{mg} \mathrm{L}^{-1}$ with a mean value of $3.5 \mathrm{mg} \mathrm{L}^{-1}$. Greywater from the different residential estates had mean DO values that ranged from $2.7-$ $5.2 \mathrm{mg} \mathrm{L}^{-1}$ (Fig. 2, Table 1). The clean water sources sampled had a DO concentration range of between 5.4 to $7.1 \mathrm{mg}$ $\mathrm{L}^{-1}$. From the different cleaning operations, mean DO of the 
Table 1. Physico-Chemical Properties and Bacteriological Properties of Greywater Samples Collected from Different Sources at Homa Bay Town

\begin{tabular}{|c|c|c|c|c|c|c|}
\hline \multicolumn{2}{|c|}{ Property/Source } & \multirow{2}{*}{$\begin{array}{c}\text { Lake } \\
599.7\end{array}$} & \multirow{2}{*}{$\begin{array}{c}\text { Makongeni } \\
1391.9\end{array}$} & \multirow{2}{*}{$\begin{array}{c}\begin{array}{c}\text { Shauri } \\
\text { Yako }\end{array} \\
1119.7\end{array}$} & \multirow{2}{*}{$\begin{array}{c}\text { Sofia } \\
1420.6\end{array}$} & \multirow{2}{*}{$\begin{array}{l}\text { Town } \\
654.5\end{array}$} \\
\hline Conductivity & Mean & & & & & \\
\hline & Range & $159-844$ & $194-3810$ & $76-4470$ & $60-4290$ & $483-826$ \\
\hline \multirow{2}{*}{$\begin{array}{l}\text { Diss Oxygen } \\
\mathrm{mg} \mathrm{L}^{-1}\end{array}$} & Mean & 3.5 & 2.7 & 3.7 & 3.6 & 5.2 \\
\hline & Range & $1.7-6.1$ & $0.7-5.9$ & $0.0-8.0$ & $0.0-7.0$ & $4.0-6.4$ \\
\hline \multirow{2}{*}{$\begin{array}{c}\mathrm{pH} \\
\mathrm{pH} \text { units }\end{array}$} & Mean & 9.2 & 9.1 & 9.2 & 9.2 & 8.2 \\
\hline & Median & $7.1-9.5$ & $5.3-9.6$ & $5.0-10.3$ & $6.2-10.2$ & $6.8-9.7$ \\
\hline \multirow{2}{*}{$\begin{array}{c}\text { Salinity } \\
\text { ppt }\end{array}$} & Mean & 0.1 & 0.5 & 0.4 & 0.5 & 0.1 \\
\hline & Range & $0.0-0.2$ & $0.0-1.9$ & $0.0-2.3$ & $0.0-2.2$ & $0.0-0.2$ \\
\hline \multirow{2}{*}{$\begin{array}{c}\text { Temperature } \\
{ }^{\circ} \mathrm{C}\end{array}$} & Mean & 23.8 & 24.7 & 24.6 & 24.9 & 26.3 \\
\hline & Range & $21.2-27.3$ & $22.3-27.1$ & $13.6-27.5$ & $18.8-28.0$ & $25.8-26.8$ \\
\hline $\mathrm{BOD}_{5} \mathrm{mg} \mathrm{L}^{-1}$ & Range & & $1800-4850$ & $440-3800$ & $270-6250$ & 560 \\
\hline \multirow{2}{*}{$\begin{array}{l}\text { Tot. Coliforms } \\
\text { CFU x } 10^{6}\end{array}$} & Mean & 2.3 & 4.4 & 4.4 & 4.3 & 6.5 \\
\hline & Range & $1.5-3.2$ & $1.6-7.4$ & $1.8-7.6$ & $1.3-7.0$ & $6.1-6.8$ \\
\hline \multirow{2}{*}{$\begin{array}{l}\text { Fecal Coliforms } \\
\text { CFU x } 10^{5}\end{array}$} & Mean & 0.50 & 2.91 & 2.77 & 2.20 & 0.34 \\
\hline & Range & $0.37-0.58$ & $0.03-6.30$ & $0.03-6.30$ & $0.04-7.4$ & $0.29-0.40$ \\
\hline
\end{tabular}

greywater ranged from $3.5-4.9 \mathrm{mg} \mathrm{L}^{-1}$ (Fig. 3, Table 2). One way ANOVA tests revealed that the difference in DO among greywater sources and greywater types was not significant $(\mathrm{F}=0.68, \mathrm{P}=0.6$ and $\mathrm{F}=0.37, \mathrm{P}=0.7$ respectively). Greywater $\mathrm{pH}$ values ranged from 5.0 to 10.3 with a median value of 9.2. Clean water samples recorded a lower $\mathrm{pH}$ range of 6.7 to 7.5 while greywater from the different residential areas had median $\mathrm{pH}$ values of between 8.2 and 9.2 (Fig. 2, Table 1). Greywater grouped according to cleaning operation had a median $\mathrm{pH}$ that ranged from 7.3 to 9.3 (Fig. 3, Table 2). The salinity of greywater samples was comparatively greater than of clean water with a range from below the limit of detection (reported as 0.0) to a maximum of 2.3. In all the clean water samples collected, salinity was below the limit of detection (Tables 1). Greywater temperatures at the time of collection ranged from 13.6 to $28.0{ }^{\circ} \mathrm{C}$ with a mean of $24.7{ }^{\circ} \mathrm{C}$. Greywater $\mathrm{BOD}_{5}$ values varied widely with a range from 270 to $6250 \mathrm{mg} \mathrm{L}^{-1}$. In general, lower values were common during the wet season, when water was relatively plentiful, while the lower values were mostly recorded during the dry season. The highest $\mathrm{BOD}_{5}$ value measured was from laundry cleaning. Overall, a wide variation in $\mathrm{BOD}_{5}$ values was characteristic of samples from the different sources as well as from the different cleaning operations.

\section{Bacterial Properties}

\section{Total Coliforms}

Total coliform (TC) counts in greywater from various household operations ranged from 1.3 to 7.6 million colony forming units (CFUs) per $100 \mathrm{~mL}$ with a mean of 4.34 million CFUs per $100 \mathrm{~mL}$ (Table 1). The highest and lowest TC counts were recorded in greywater from dish washing. Mean TC counts of greywater from different greywater sources ranged from 2.4 (Lake) to 6.5 (Town) million CFUs per 100
mL (Fig. 4, Table 1). Overall, greywater samples from cleaning operations next to Lake Victoria had a comparatively lower load of TC (mean 2.4 million CFU/ $100 \mathrm{~mL}$ ) than samples from other sources. Mean comparison using a one way ANOVA test revealed that the difference in TC counts among the different greywater sources was not significant $(\mathrm{F}$ $=2.03, \mathrm{P}=0.1$ ). Mean TC counts of the greywater from different cleaning operations varied between 4.2 and 5.1 million CFUs (Fig. 5, Table 2). An ANOVA test revealed that the difference in TC counts among the various types of greywater was not significant $(\mathrm{F}=0.37, \mathrm{P}=0.7)$.

\section{Fecal Coliforms}

Fecal coliforms (FC) counts in household greywater ranged from $3.0 \times 10^{3}$ to $7.4 \times 10^{5} \mathrm{CFU} / 100 \mathrm{~mL}$ with a mean of $2.51 \times 10^{5} \mathrm{CFU} / 100 \mathrm{~mL}$. The lowest and highest FC counts were recorded in greywater from laundry washing. Mean FC counts in greywater from different sources varied between $5.0 \times 10^{4}$ (Town) and $2.91 \times 10^{5}$ (Makongeni) CFU per $100 \mathrm{~mL}$ (Fig. 4, Table 1). As in the case of $\mathrm{TC}$, mean comparison of $\mathrm{FC}$ counts using a one way ANOVA test revealed that the difference in $\mathrm{FC}$ among the different greywater sources was not significant $(\mathrm{F}=0.99, \mathrm{P}=$ 0.38). From the different cleaning operations, greywater from bathing recorded the lowest mean FC colony count $\left(1.54 \times 10^{5}\right.$ CFU per $\left.100 \mathrm{~mL}\right)$ while that from the kitchen had the highest mean colony count $\left(3.22 \times 10^{5} \mathrm{CFU}\right.$ per 100 mL) (Fig. 5, Table 2). Similarly, a one way ANOVA test revealed that there was no significant difference in FC counts among cleaning operations $(\mathrm{F}=0.49, \mathrm{P}=0.74)$.

\section{Pathogenic Bacteria}

Over the study period, presence of the potentially pathogenic bacteria from the genera Salmonella, Shigella and $\mathrm{Vi}$ brio was recorded in greywater from the various cleaning operations. Overall, Salmonella was the most frequent and 

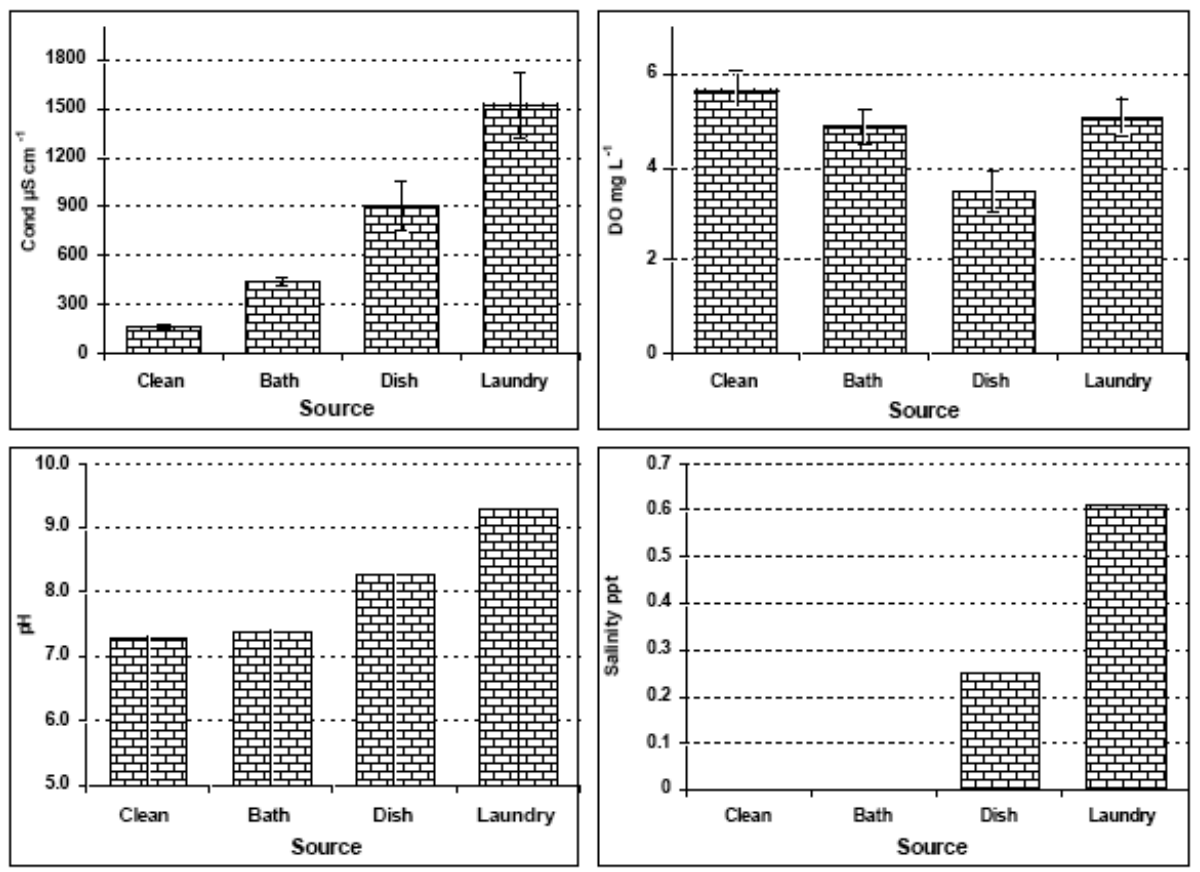

Fig. (3). Mean levels of electrical conductivity, dissolved oxygen, salinity and median $\mathrm{pH}$ of greywater samples obtained from different cleaning operations in Homa Bay. Vertical bars represent \pm SE.
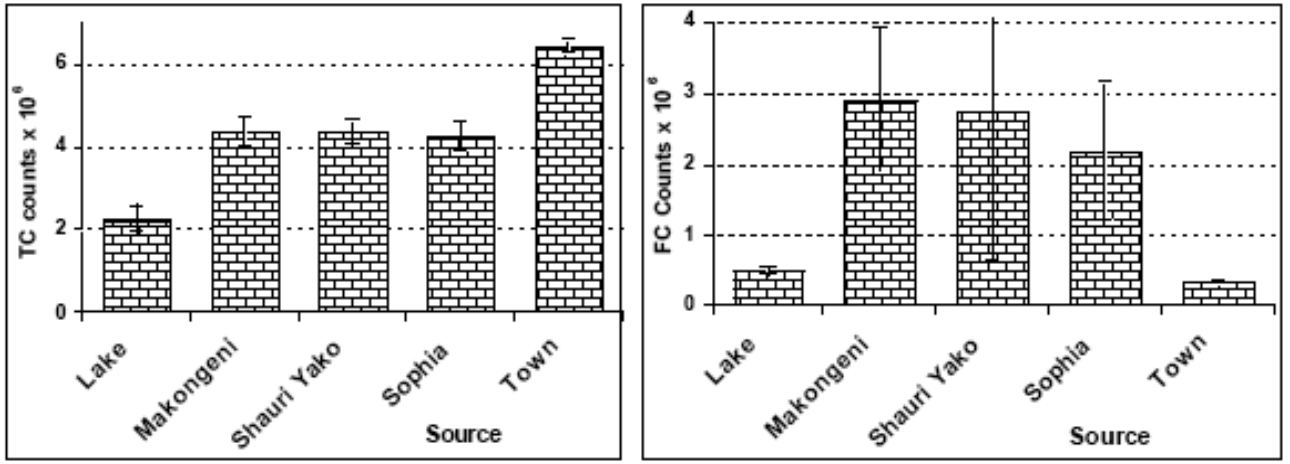

Fig. (4). Mean levels of total coliforms (TC) and fecal coliforms (FC) in greywater samples obtained from different sources in Homa Bay. Vertical bars represent \pm SE.

its presence was recorded in $31 \%$ of all the samples collected. Shigella and Vibrio cholerae were recorded in $18 \%$ and $7 \%$ respectively of all the greywater samples collected over the study period. The three potentially pathogenic bacteria were absent in all the clean water samples collected except for the presence of Vibrio cholerae in a rain water sample collected from Sofia Estate. Salmonella, Shigella and Vibrio cholerae were present in 44, 31 and 19 percent of greywater samples from Makongeni Estate and in 27, 19 and 5 percent of samples from Shauri Yako Estate in the same order. In greywater samples from Sofia Estate, Salmonella, Shigella and Vibrio cholerae were present in 36, 12 and 8 percent of the greywater samples. The three potentially pathogenic bacteria were absent in greywater from the lake and town sources. Salmonella, Shigella and Vibrio cholerae were present in 33, 15 and 17 percent of greywater water samples from laundry activities respectively and in 31,22 and 9 percent of greywater from dish washing activities in the same order. Salmonella and Vibrio cholerae were both present in 33 percent of greywater from bathing activities.

\section{DISCUSSION}

A wide variation in the physico-chemical properties of greywater from the various sources can be attributed to the difference in the intensity of use of water before it qualifies to be discarded as well as the differences in the origin of dirt that the items being cleaned were exposed to. Absence of a significant variation in the electrical conductivity of greywater samples from the different residential areas suggests that there is no significant variation in concentration of dissolved inorganic salts in the detergents used as well as the dissolved salt content of dirt contaminants of different residential areas. However, a significant difference in EC of greywater from different cleaning operations can be attributed to the possible difference in the quantity of dissolved ions in the detergents used for the different cleaning operations. A high EC of greywater from laundry cleaning is consistent with the findings of other studies. A study carried out in households at Kitgum (Uganda) reported that laundry greywater had higher EC than both bath and kitchen greywater [20]. 

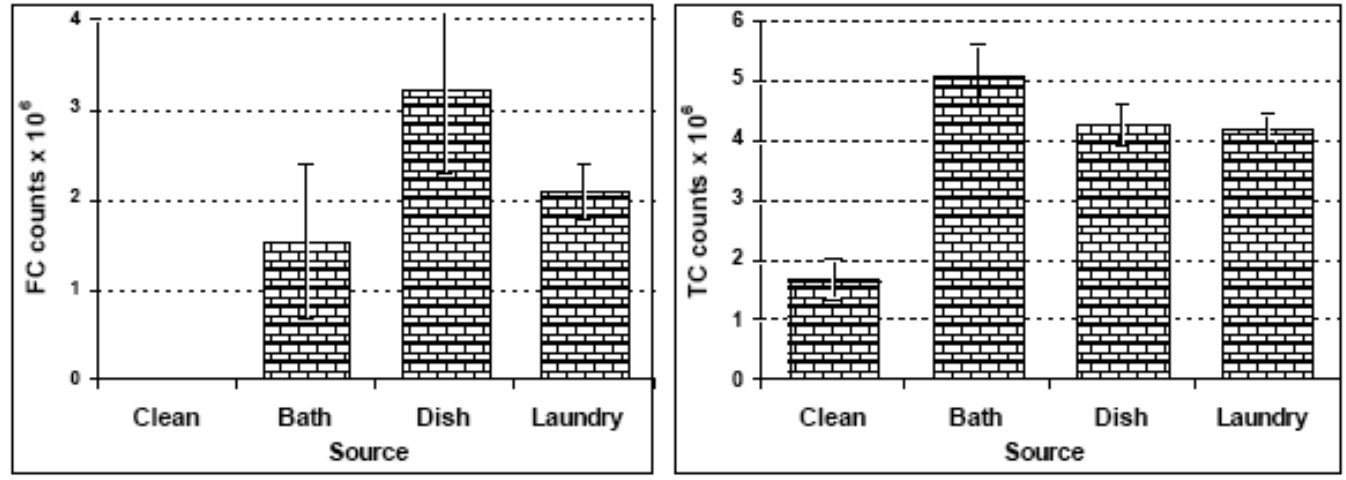

Fig. (5). Mean levels of total coliforms (TC) and fecal coliforms (FC) in greywater samples obtained from different cleaning operations in Homa Bay. Vertical bars represent \pm SE.

Table 2. Physico-Chemical Properties and Bacteriological Properties of Greywater and Clean Water Samples Collected from Different Cleaning Operations at Homa Bay Town

\begin{tabular}{|c|c|c|c|c|c|}
\hline \multicolumn{2}{|c|}{ Property/Source } & \multirow{2}{*}{$\frac{\text { Clean }}{162.3}$} & \multirow{2}{*}{$\frac{\text { Bath }}{437.0}$} & \multirow{2}{*}{$\begin{array}{c}\text { Dish } \\
906.1\end{array}$} & \multirow{2}{*}{$\begin{array}{c}\text { Laundry } \\
1526.7\end{array}$} \\
\hline Conductivity & Mean & & & & \\
\hline & Range & $143-187$ & $240-588$ & $60-4110$ & $225-4470$ \\
\hline \multirow{2}{*}{$\begin{array}{l}\text { Diss Oxygen } \\
\mathrm{mg} \mathrm{L}^{-1}\end{array}$} & Mean & 5.7 & 4.9 & 3.5 & 3.7 \\
\hline & Range & $4.5-7.1$ & $4.0-5.7$ & $0.0-6.9$ & $0-7.96$ \\
\hline BOD mg L ${ }^{-1}$ & Range & & & $470-4450$ & $410-6250$ \\
\hline \multirow[t]{2}{*}{$\mathrm{pH}$} & Mean & 7.3 & 7.4 & 8.3 & 9.3 \\
\hline & Range & $6.7-7.5$ & $6.8-9.2$ & $5.0-10.2$ & $7.3-10.3$ \\
\hline \multirow{2}{*}{$\begin{array}{l}\text { Salinity } \\
\text { ppt }\end{array}$} & Mean & 0.0 & 0.0 & 0.3 & 0.6 \\
\hline & Range & $0-0$ & $0-0$ & $0-2.1$ & $0-2.3$ \\
\hline \multirow{2}{*}{$\begin{array}{c}\text { Temperature } \\
{ }^{\circ} \mathrm{C}\end{array}$} & Mean & 23.7 & 25.8 & 30.9 & 24.8 \\
\hline & Range & $20.0-27.6$ & $24.2-26.8$ & $13.6-22.8$ & $13.9-27.8$ \\
\hline \multirow{2}{*}{$\begin{array}{l}\text { T. Coliforms } \\
\text { CFU x } 10^{6}\end{array}$} & Mean & 1.7 & 5.1 & 4.3 & 4.2 \\
\hline & Range & $1.3-2.4$ & $3.5-6.1$ & $1.3-7.6$ & $1.6-7.4$ \\
\hline \multirow{2}{*}{$\begin{array}{l}\text { Fecal Coliforms } \\
\text { CFU x } 10^{5}\end{array}$} & Mean & & 1.54 & 3.22 & 2.10 \\
\hline & Range & & $0.04-4.3$ & $0.05-6.2$ & $0.03-7.4$ \\
\hline
\end{tabular}

A mean greywater DO value of $3.5 \mathrm{mg} \mathrm{L}^{-1}$ suggests that the anaerobic microbial growth phase in the greywater discharged commences immediately. This implies that the greywater samples cannot be stored for long as the depletion of dissolved oxygen is most likely to occur in a few hours. A storage period of 48 hours has been given for the depletion of dissolved oxygen in greywater after, which anaerobic process take over the degradation process [21]. Hence it would be advisable to carry out some initial aeration of greywater generated at Homa Bay before being discarded into the environment to lessen deoxygenation and its associated toxicity. Greywater $\mathrm{pH}$ range from 5.0 to 10.3 was comparatively wider than that of the clean water sources (range 6.7 to 7.5 ). The low $\mathrm{pH}$ values recorded was mostly from dish washing and possibly resulted from occasions when the dishes with food remains were soaked overnight and washed in the morning. In some households, cut lemon was added to the cleaning water as an antiseptic. The comparatively high $\mathrm{pH}$ values of bath and laundry greywater is in line with observations made elsewhere [22] and is mainly due to the alkalinity of the detergents and soaps used. Past research work have recommend a $\mathrm{pH}$ range of $5.0-8.0$ for non potable interior and exterior wastewater reuse [23]. Hence a significant portion of the greywater exceeded this $\mathrm{pH}$ range and would therefore require treatment before reuse. Water use for various cleaning operations increased greywater salinity by different magnitudes depending on the intensity of use and type of use. A wide fluctuation in the $\mathrm{BOD}_{5}$ values $\left(270-6250 \mathrm{mg} \mathrm{L}^{-1}\right)$ can be explained by variation in the amount of washing that wash water is used for before being discarded. During the study, it was noted that families, especially in the low income areas, reused wash water sev- 
eral times until the color and the volume remaining would not allow any further washing. This washing approach was most evident during the dry season when water availability was really low. Although no attempt was made to assess the type of laundry, it is also possible that some of the laundry could have been soiled by fecal matter (from child diapers etc.). Compared to BOD measurements from other parts of the world, the BOD measurements at Homa Bay were much higher. For example, $\mathrm{BOD}_{7}$ values ranging from 350 to 500 mg L-1 have been reported for Swedish greywater samples [24]. Although the higher BOD values are expected in warm climate as is the case of Homa Bay, the difference in BOD values had more to do with the intensity of use of water prior to discarding as well as differences in the general level of hygiene.The findings of the total coliform (TC) and fecal coliform (FC) measurements revealed that the cleaning operations on most occasions increased the bacterial load of the water. Among the factors observed to contribute to variation in the TC and FC counts included differences in hygiene conditions, variation in water economy (some households recycle cleaning water more than others), variation in the period in which the items being cleaned had been left soaking in the cleaning water etc. Food remains and possibly overnight soaking of used utensils contributed to the comparatively higher TC counts in dish greywater while fecal contamination can explain the high FC count in laundry greywater. On the other hand, the comparatively lower TC counts in greywater samples obtained from cleaning operations next to Lake Victoria can be attributed the greater volume of water used in cleaning operations carried out next to the lake. During the study, it was observed that people washing near the lake tend to use more water in the cleaning resulting in more dilute greywater as compared to that produced by cleaning operations at home were water economy is important. An unusually high TC counts in a rain water sample collected at Sofia Estate $(2.4 \mathrm{CFU} / 100 \mathrm{~mL})$ suggests that the rain water would have been exposed to some form of bacterial contamination. However, absence of a significant difference in TC and FC counts in greywater samples from different residential areas as well as different household cleaning operations suggests that the level of hygiene in the different residential areas is more-or-less similar. An overall TC range of 1.3 -7.6 million CFU is comparatively lower than a value of $2.4 \times 10^{3}$ to $2.4 \times 10^{6}$ measured in the Dome distribution system in London [25]. An analysis of greywater from different sources in Berlin established a TC range from 10 to $10^{6} \mathrm{CFU}$ for greywater [26]. Presence of fecal coliforms is usually considered to be a more specific indicator of fecal contamination of water samples [27] as well as the possible presence of pathogenic bacteria. In many of the cases investigated, the ratio of fecal coliform to total coliforms exceeded a value of 0.1 , an indication of possible fecal contamination of greywater [28]. A high percentage of greywater samples in which pathogenic bacteria were recorded (up to $31 \%$ for Salmonella) demonstrates the risk that handlers of greywater are exposed to and confirms the need for greywater disinfection. Because pathogenic bacteria were absent in most clean water samples collected during the sampling period, it is clear that contamination occurred in the course of the cleaning operations. Presence of Vibrio cholerae in the rain water sample was a rather unusual occurrence that sup- ports the suspicion that the water sample would have been contaminated by fecal wastes. Presence of pathogenic bacteria in greywater samples have reported in earlier studies. For example, the occurrence of opportunistic pathogens, Pseudomonas aeruginosa and Staphylococcus aureus in greywater samples has been reported [12].

\section{CONCLUSIONS}

- The physico-chemical and bacterial quality of greywater generated by households at Homa Bay varies widely among households and less among the residential areas and type of use depending on the general hygiene of households, the intensity of reuse before the wastewater is discarded, and retention periods after use.

- Presence of Salmonella, Shigella and Vibrio cholerae in $31 \%, 18 \%$ and $7 \%$ of all the greywater samples collected over the study period means that the Greywater generated at Homa Bay is likely to be contaminated by pathogenic bacteria. As the practice of reusing greywater is common in the residential areas investigated, the spread of an outbreak of waterborne diseases can be very fast in the area.

We recommend that the since the residents of these areas are already practicing greywater reuse, the community should be enlightened on simple disinfection procedures for greywater prior to reuse. This will reduce the likely outbreak of waterborne diseases.

\section{ACKNOWLEDGEMENTS}

We thank the Government of Kenya for providing research permission (No. MOHEST 13/001/38 C 360). We are grateful to the Victoria Research Initative (VicRes) for financial support. Our sincere appreciation is also due to the Residents of Homa Bay town for granting us access to their houses to collect water samples and their cooperation in the exercise. For assistance in the field and in the laboratory, we thank Stephen M. Gichobi of the Department of Plant and Microbial Sciences.

\section{REFERENCES}

[1] Anon. 2004. Strategy for Swedish support to the Lake Victoria Basin. 2004-2006. Ministry of Foreign Affairs, Stockholm. Available www.sweden.gov.se [accessed Nov. 16, 2010].

[2] P. Len, G. Zeeman, and G. Lettinga (Eds), Decentralised Sanitation and Reuse: Concepts, systems and implementation, IWA Publishing, 2001.

[3] E. Madungwe, and S. Sakuringwa, "Greywater reuse: A strategy for water demand management in Harare?" Physics and Chemistry of the Earth, Parts A/B/C, vol. 32, pp. 1231-1236, 2007.

[4] E.J. Chaggu, "Sustainable Environmental Protection Using Modified Pit latrines", Ph.D. Thesis, Wageningen University and Research Centre, The Netherlands, 2004.

[5] O.R. Al-Jayyousi, "Greywater reuse: towards sustainable management” Desalination, vol. 156, pp. 181-192, 2003.

[6] G. Boghos, "Adoption of greywater treatment and reuse technology in a cluster of six towns in lebanon", International Water Demand Conference, Jordan, 2004.

[7] H. Yang and K.C. Abbaspour, "Analysis of wastewater reuse potential in Beijing”, Desalination, vol. 212, pp. 238-250, 2007

[8] D. Fatta-Kassinos, I.K. Kalavrouziotis, P.H. Koukoulakis, and M.I. Vasquez, "The risks associated with wastewater reuse and xenobiotics in the agroecological environment", Science of The Total En- 
vironment, In Press (Available online on doi:10.1016/j.scitotenv.2010.03.036)

[9] J. Chu, J. Chen, C. Wang, and P. Fu, "Wastewater reuse potential analysis: implications for China's water resources management" Water Research, vol. 38, pp. 2746-2756, 2004.

[10] M. Ahmed, S. Prathapar, A. Al-Jamrah, A. Al-Maskiri, and A. AlBelushi, "Greywater reuse in arid countries: problems and possibilities”, Sultan Qaboos University, 2001.

[11] A. Gross, N. Azulai, G. Oron, Z. Ronen, M. Arnold and A. Nejidat, "Environmental impact and health risks associated with greywater irrigation: a case study", Water Science and Technology, vol. 52, pp. 161-169, 2005.

[12] G.P. Winward, L.M. Avery, R. Frazer-Williams, M. Pidou, P. Jeffrey, "A study of the microbial quality of grey water and an evaluation of treatment technologies for reuse", Ecological Engineering, vol. 32, pp. 187-197, 2008.

[13] A. Morel and S. Diener, "Greywater Management in Low and Middle Income Countries, Review of Treatment Systems for Households or Neighbourhoods", Sandec (Swiss Federal Institute of Aquatic Science and Technology), Dubendorf, Switzerland, 2006.

[14] E. Nolde, "Greywater recycling systems in Germany - results, experience and guidelines", Water Science and Technology, vol. 51, pp. 203-210, 2005.

[15] M. Lamine, L. Bousselmi, and A. Ghrabi, "Biological treatment of greywater using sequencing bathc reactor", Desalination, vol. 215, pp. 127-132, 2007.

[16] B. Imhof, and J. Muhlemann, "Greywater Treatment on Household Level in Developing Countries - A state of the Art Review", Department of Environmental Sciences at the Swiss Federal Institute of Technology (ETH), Zurich, Switzerland, 2006.

[17] United Nations, "Lake Victoria City Development Strategies for Improved Environment and Poverty Reduction", Homa Bay Town Profile, 2006.
[18] APHA, Standard Methods for the Examination of Water and Wastewater, American Public Health Association, $20^{\text {th }}$ Ed., Washington DC, 1998.

[19] M. Cheesbrough, District Practice Laboratory in Tropical Countries, Part 2. Cambridge University Cambridge, Press: 2000.

[20] R. Kulabago, J. Kinobe, J. Mujunga, S. Olwenyi, and K. Sleytr, "Greywater use in peri-urban households in Kitgum, Uganda", Sustaniable Sanitation Practice, Issue 1, pp. 16-24.

[21] A. Dixon, D. Butler, A. Fewkes, and M. Robinson, "Measurement and modeling of quality changes in stored untreated grey water", Urban Water, vol. 1, pp. 293-306, 2000.

[22] E. Erickson, K. Auffarth, M. Henze, A. Ledin, "Characteristics of grey wastewater", Urban Water, vol. 4, pp. 85-104, 2002.

[23] R.G. Kevin, and M.E. Rinker, "Sustainable water resources and urban reuse technology", in the Proceedings of the First International Conference on Sustainable Construction, Tampa, Florida, 1994; pp. 807-816.

[24] H. Palmquist, and J. Hanaeus. Hazardous substances in separately collected grey- and blackwater from ordinary Swedish households. Science of the Total Environment, vol. 348, pp. 151-165. 2005.

[25] R. Birks, J.S. Colbourne, S. Hills, and R. Hobson, "Microbiological water quality in a large in-building, water recycling facility", Water Science and Technology, vol. 50, pp. 165-172, 2004.

[26] E. Nolde, "Greywater reuse systems for flushing in multi-storey buildings - over ten years experience in Berlin", Urban Water, vol. 1, pp. 275-284, 2000.

[27] R.M. Maier, I.L. Pepper, and C.P. Gerba, Environmental Microbiology. Academic Press: San Diego, CA, 2000.

[28] L.W. Sinton, R.K. Finlay, and D.J. Hannah "Distinguishing human from fecal contamination: a review". New Zealand Journal of Marine and Freshwater Research, vol. 32, pp. 323-348, 1998.

Received: March 11, 2011

Revised: July 12, 2011

Accepted: July 15, 2011

(C) Kotut et al.; Licensee Bentham Open.

This is an open access article licensed under the terms of the Creative Commons Attribution Non-Commercial License

(http://creativecommons.org/licenses/by-nc/3.0/g) which permits unrestricted, non-commercial use, distribution and reproduction in any medium, provided the work is properly cited. 